\title{
The potential role of ammonia as a signal molecule for procellariiform seabirds
}

\author{
Gabrielle A. Nevitt ${ }^{1, *}$, Dana M. Bergstrom ${ }^{2}$, Francesco Bonadonna ${ }^{3}$ \\ ${ }^{1}$ Center for Animal Behavior, Section of Neurobiology, Physiology and Behavior, University of California, Davis, \\ California 95616, USA \\ ${ }^{2}$ Australian Antarctic Division, 203 Channel Highway, Kingston, Tasmania 7050, Australia \\ ${ }^{3}$ Behavioural Ecology Group, Centre National de la Recherche Scientifique, Centre d'Ecologie Fonctionnelle et \\ Evolutive (CNRS-CEFE), 1919 route de Mende, 34293 Montpellier, Cedex 5, France
}

\begin{abstract}
Procellariiform seabirds (petrels, albatrosses and shearwaters) navigate vast distances over seemingly featureless ocean habitat by mechanisms that are not well understood. These birds have large olfactory bulbs, and the use of smell has been implicated in both foraging and homing behavior. While many olfactory cues relevant to these behaviors have been identified, ammonia is a potentially significant, biogenic, scented compound that has not been studied in this context. Ammonium $\left(\mathrm{NH}_{4}{ }^{+}\right)$constitutes a primary waste product produced by many of the prey species on which procellariiforms forage. Nitrogen waste products, including volatilized ammonia $\left(\mathrm{NH}_{3}\right)$, also scent the terrestrial landscape of sub-Antarctic islands where newly breeding procellariiform seabirds recruit and raise their young. Since an ability to smell ammonia may be relevant to both prey detection and locating colonies or islands, we used a non-invasive, behavioral assay to examine whether this scented compound is detectable by a candidate test species, the blue petrel Halobaena caerulea Gmelin. Our results suggest that these birds can detect volatilized ammonia within a concentration range that they may naturally encounter $\left(10^{-11}\right.$ to $\left.10^{-5} \mathrm{M}\right)$, and point to ammonia as a potential signal molecule in the sub-Antarctic.
\end{abstract}

KEY WORDS: Petrel $\cdot$ Ammonia $\cdot$ Homing $\cdot$ Foraging $\cdot$ Antarctic $\cdot$ Navigation

\section{INTRODUCTION}

Procellariiform seabirds navigate the world's oceans by mechanisms that are not well understood. These birds have an excellent sense of smell, and olfaction has been linked to both foraging and homing to specific nest sites, particularly in burrowing species. With respect to foraging, the use of olfaction has been studied in greatest detail in sub-Antarctic species (for review see Nevitt 2000, Nevitt \& Bonadonna 2005a). Our current understanding is that procellariiforms use odor cues at both larger (1000s of square kilometers), and smaller (10s or 100s of square kilometers) spatial scales (Nevitt 2000). At large spatial scales, changes in the odor profile over the ocean demarcate productive zones in what appears as a featureless landscape to humans. These productive zones are areas where prey patches are likely to be encountered. Once a bird arrives at a productive area, the changing odor landscape triggers a shift in behavior to a small-scale, area-restricted search. Birds then use a combination of visual and olfactory cues to pinpoint prey patches. Observational and experimental evidence collected from species assemblages near South Georgia suggests that the sensory modality that a bird typically uses depends on both the bird species and the foraging context (e.g. Nevitt 1999, Nevitt \& Veit 1999, Nevitt et al. 2004). Some species zigzag upwind to focus activity to odor sources (e.g. Nevitt et al. 1995, Nevitt 2000), whereas others use visual cues provided by aggregations of prey, foraging seabirds and marine mammals (Silverman et al. 2004).

Procellariiform seabirds respond to a variety of scented compounds associated directly or indirectly with prey, including dimethyl sulfide (DMS), a sulfur- 
based compound released by phytoplankton. DMS emissions become elevated in surface seawater associated with oceanic features such as upwelling zones and shelf waters, where both phytoplankton and prey tend to aggregate (for review see Nevitt 2000). DMS emissions also increase locally during cell destruction associated with zooplankton grazing (e.g. Dacey \& Wakeham 1986, Daly \& DiTullio 1996, Kasamatsu et al. 2004). A range of other scented compounds are also released, either through excretion or maceration, as organisms are broken up during the predation process (see discussion in Nevitt et al. 2004). These compounds include nitrogen waste products which, like DMS, may provide birds with proximate cues for detecting krill swarms. For example, freshly caught Antarctic krill Euphausia superba Dana excrete ammonium $\left(\mathrm{NH}_{4}{ }^{+}\right)$on the order of 1.6 to $2.8 \mathrm{nmol} \mathrm{mg}^{-1}$ dry mass $\mathrm{h}^{-1}$ (Atkinson \& Whitehouse 2000). Calculations from laboratory, ship-based, experiments suggest that copepods and small euphausids excrete ammonium into the pelagic zone around South Georgia Island at a rate of approximately $1 \mathrm{mmol} \mathrm{m}^{-2} \mathrm{~d}^{-1}$ (Atkinson \& Whitehouse 2001).

Nitrogen waste products may also play a role in how birds navigate to colony sites or islands. Islands provide breeding habitat for marine mammals and seabirds and consequently receive substantial quantities of marine-derived nitrogen as wastes. These wastes give rise to both atmospheric (volatilized $\mathrm{NH}_{3}$ ) and marine ammonium $\left(\mathrm{NH}_{4}{ }^{+} / \mathrm{NH}_{3}\right)$ plumes that are often detectable by humans kilometers downwind (Erskine et al. 1998, see also Rankin \& Wolff 2000). In a review of population sizes of penguins, seals, and their associated excrement rates on Macquarie Island, Erskine et al. (1998) calculated that over $3700000 \mathrm{t}$ of dry mass excrement was deposited annually, and this converted to nearly $240 \mathrm{t}$ of nitrogen. Moreover, the contribution of $\sim 60000$ burrowing petrels of various species (see Shirihai 2002) was not included in this calculation because uric acid from birds is rapidly mineralized, releasing ammonia gas. On another sub-Antarctic island (Marion Island), Lindeboom (1984) estimated that over $10 \%$ of nitrogen from penguin colonies eventually reached inland vegetation as volatilized ammonia. Thus, from a human perspective, increased volatilized ammonia contributes substantially to the odor landscape associated with the island habitat on which birds nest. Even though ammonia is both a potent olfactory and trigeminal stimulant to humans, most bird species that have been tested (including rock doves Columbia livia, red-winged blackbirds Agelaius phoeniceus, European starlings Sturnus vulgaris and gray partridges Perdiz perdix) cannot physiologically or behaviorally detect this compound (for review see Clark 1997).

Since volatilized ammonia may be important in both prey detection and locating colonies or inhabited islands, the aim of this study was to determine whether ammonia is detectable to a candidate procellariiform species within a concentration range that is potentially biologically relevant to both foraging and navigation. Therefore, although absolute sensitivity thresholds in birds typically range from $10^{-7}$ to $10^{-5} \mathrm{M}$ across a variety of olfactory stimuli and species (see Roper 1999 for review), the lowest concentration we tested was 4 orders of magnitude lower $\left(10 \mathrm{pM}\right.$ or $\left.10^{-11} \mathrm{M}\right)$ than the lowest expected threshold value. Experiments were performed on the blue petrel Halobaena caerulea Gmelin, a common species that nests in burrows throughout the sub-Antarctic. To reliably test a concentration series in the field, we used a non-invasive, behavioral assay that was developed to test responses of domestic chicks to odor stimuli in laboratory situations (Porter et al. 1999). We have previously adapted this method to examine olfactory sensitivity in both blue petrels and diving petrels (Cunningham et al. 2003). Based on our findings, we explore two potential roles for ammonia as signal molecule for procellariiform seabirds.

\section{MATERIALS AND METHODS}

The study was conducted at Ile Verte $\left(49^{\circ} 51^{\prime} \mathrm{S}\right.$, $70^{\circ} 05^{\prime} \mathrm{E}$ ) from January 8 to 16,2004 . Ile Verte is situated on the eastern side of the Kerguelen Archipelago, just south of the Antarctic Convergence. Breeding populations of blue petrels at Kerguelen have been estimated to approach 1 to 2 million pairs (Weimerskirch et al. 1989).

The Porter method. We tested the olfactory responses of 24 blue petrel chicks using the Porter method. This method was developed as a relatively simple technique for testing responses of domestic chicks to odors in laboratory settings (Porter et al. 1999). Chicks enter a sleep-like state and responses are recorded as test odors are puffed onto their nostrils. This technique has several advantages for our applications in that it is completely non-invasive, does not deleteriously impact fledging success, and has previously been used to test the responses of blue petrel chicks in the field (Cunningham et al. 2003). While the Porter method does not work well with adult birds, results from earlier work suggest that chick responses to odor stimuli reflect those of adults in at-sea experiments (Cunningham et al. 2003).

To run a trial, a chick was removed from its burrow, placed in a cotton bag and transported to a well-ventilated field hut $(4 \times 6 \mathrm{~m})$ within $500 \mathrm{~m}$ of the colony. The chick was then placed in a holding chamber lined with a clean paper towel. The holding chamber was made of black, flexible corrugated plastic folded to form a rec- 
tangular box (approximately $10 \times 5 \times 5 \mathrm{~cm}$ ) open at both ends. The chamber was placed on a small platform to allow easy access to the chick's nostrils. The chick was positioned so that its head protruded from one end and the chamber walls were in contact with the bird's body. Once the chick was positioned in the chamber, it quickly (within $3 \mathrm{~min}$ ) entered a sleep-like state in which its head drooped slightly and its eyes closed. As in earlier studies, chicks were considered to be 'asleep' when their eyes were closed, their head became droopy, and their legs and wings relaxed. Chicks were left to sleep for at least 3 min before initiating a trial.

During a trial, we exposed the chick to a series of 3 increasing ammonia solution concentrations (10 pM, $10 \mathrm{nM}, 10 \mu \mathrm{M}$ in water, $\mathrm{pH}$ 7.0) with a control (water) inserted randomly into the sequence. Vapor concentrations were not measured, but were conservatively estimated to be 1 order of magnitude less than solution concentrations (e.g. Sawyer \& McCarty 1978). Stimuli were presented by puffing odor above the chicks' nostrils using a $500 \mathrm{ml}$ Nalgene ${ }^{\circledR}$ squeeze bottle. The tip of the bottle was positioned $\sim 3 \mathrm{~cm}$ from the nostrils. The bottle was then squeezed 1 to 2 times in $5 \mathrm{~s}$, producing brief puffs of odorant-saturated air near the bird's nostrils. Responses to odorant presentations were recorded for $1 \mathrm{~min}$ and scored categorically as positive (Score $=1$; biting movements, vocalizations, distinct head or body movements) or negative (Score $=0$; typically no reaction) for each bird (modified from Porter et al. 1999). Experimental observations and scoring were done 'blind': the person delivering the stimulus and recording the response did not know the identity or concentration of the stimulus being delivered. In addition, the person who set up the odor sequence was not present during the experimental trial. If the chick woke up during a test, we waited for up to $3 \mathrm{~min}$ for it to return to a sleep-like state. We then allowed the bird to sleep for 1 min before proceeding with the next stimulus. If the bird did not fall asleep within 3 min, we aborted the experiment and returned the bird to its burrow.

All experiments were conducted within a narrow temperature range $\left(10\right.$ to $\left.13^{\circ} \mathrm{C}\right)$ during daylight hours, when parents were absent from the burrow. Chicks were transported and tested one at a time and spent less than 30 min away from the nest. Each chick was weighed after testing, returned to its burrow, and was tested only once. Burrows were monitored again prior to fledging to check for any deleterious effects of the experimental procedure. Although we left the island just prior to fledging, we observed no mortality among the chicks that were tested; weight gain and wing chord growth were within normal parameters (Jouventin et al. 1985).

Odors. Odorant stimuli (100 ml) were prepared in serial dilution from stock solutions (1 mM; SigmaAldrich). Solutions were prepared using new Hamilton syringes and glassware. During preliminary trials, we noticed that distilled water prepared from local sources in the Kerguelen laboratories had an ammonia odor. Thus, to avoid potential contamination from ambient water sources, all solutions were prepared in bottled spring water $\left(\right.$ Evian $\left.^{\circledR}\right)$ imported from France rather than locally available distilled water. Test solutions were transferred to clean Nalgene ${ }^{\circledR}$ squeeze bottles. Bottles were allowed to sit for at least $3 \mathrm{~h}$ at ambient temperature to equilibrate the headspace.

Statistical analysis. To determine whether there was a difference among treatment effects, scores were analyzed using a Friedman test (in essence, a nonparametric, blocked ANOVA). Dunnett's multiple comparison test was used to determine which of the non-control treatments differed significantly from the control treatment (Daniel 1990). We next used a rank ANOVA to examine whether the condition of being fed the previous night impacted the dose response. Fed status was indicated by a marked distension of the crop. This analysis followed the structure of a repeated-measures ANOVA, with feeding status considered as a betweensubject factor, and dose considered as a within-subject factor (Daniel 1990).

As in earlier studies (Cunningham et al. 2003), we also investigated the relationships between age indicators (chick weight and tarsus length) and chick responsiveness to treatments. Here we calculated Spearman's $\rho$ coefficient, a measure of association based on ranked data. We looked at mean behavioral response by averaging each chick's scores for control and ammonia treatments. A significant test statistic indicated a nonzero rank correlation (Zar 1996). All analyses were performed using SYSTAT software.

\section{RESULTS}

The 24 Halobaena caerulea chicks we tested ranged in weight from 85 to $215 \mathrm{~g}$ (mean \pm SE was $166.9 \pm 6.5 \mathrm{~g}$ ), suggesting that chicks were mid-way through their development to fledging at the time of testing; (Jouventin et al. 1985). Average $( \pm \mathrm{SE})$ wing chord and tarsus measurements were consistent with this approximation (wing chord: $45.4 \pm 2.1 \mathrm{~mm}$; tarsus: $28.2 \pm 0.8 \mathrm{~mm}$ ).

Mean scores for control and the 3 test stimuli were significantly different (Fig. 1, Friedman test, $F=3.21$; $\mathrm{df}=3 ; \mathrm{p}<0.03)$; All application concentrations differed significantly from the control $(\mathrm{p}<0.05$, Dunnett's multiple comparison test), suggesting that chicks could detect ammonia at solution concentrations from $10 \mathrm{pM}$ to $10 \mu \mathrm{M}\left(10^{-11}\right.$ to $\left.10^{-5} \mathrm{M}\right)$.

We found that being fed the previous night had no impact on the dose response to ammonia, suggesting that chicks were just as likely to respond to volatilized 


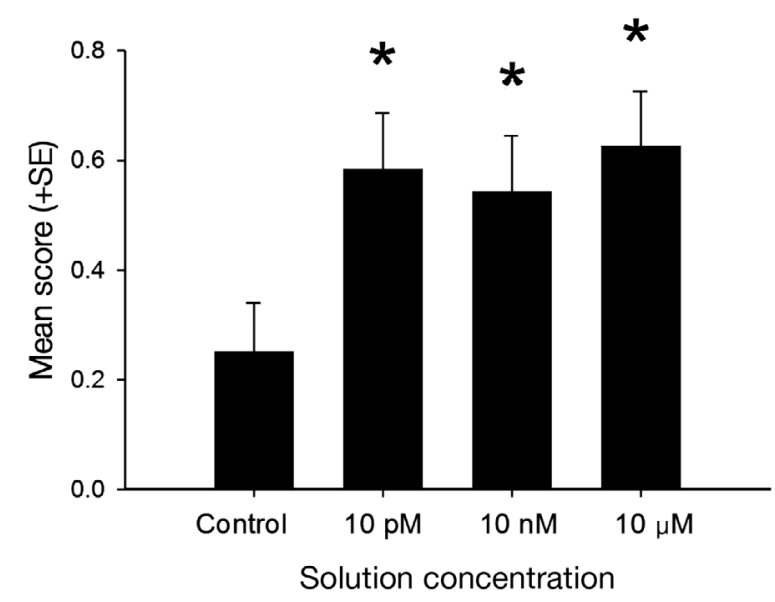

Fig. 1. Halobaena caerulea. Average behavioral responses of 24 blue petrel chicks to ammonia using the Porter method. Mean (+SE) scores are plotted for responses to control and to each solution concentration. ${ }^{*}$ Significant difference from control response $(\mathrm{p}<0.05)$

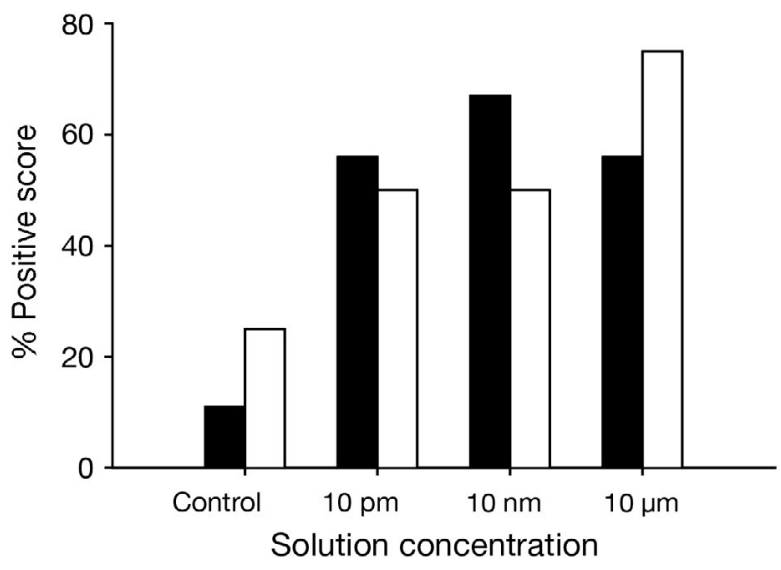

Fig. 2. Halobaena caerulea. Responses to ammonia of fed (black bars; $N=9$ ) vs. unfed (white bars; $N=12$ ) chicks, showing percentage of positive scores for control and for each solution concentration. Feeding status of 3 birds could not be determined and these were therefore not included in this analysis

ammonia at the concentrations tested, regardless of whether or not they were hungry (Fig. 2, Fed: $\mathrm{N}=9$; Unfed: $\mathrm{N}=12$; rank ANOVA: $F=0.46 ; \mathrm{p}=0.98$; We had no data for feeding state for 3 chicks). Similarly, we found no correlation between average score and either weight (Spearman's $\rho=0.06 ; \mathrm{p}=0.73 ; \mathrm{N}=24$ ) or tarsus length (Spearman's $\rho=-0.15 ; \mathrm{p}=0.50 ; \mathrm{N}=24$ ), suggesting that chicks responded similarly to test stimuli, regardless of their age.

\section{DISCUSSION}

Our results demonstrate that blue petrel chicks can detect volatilized ammonia at solution concentrations as low as $10 \mathrm{pM}\left(10^{-11} \mathrm{M}\right)$. While this concentration is well below the detection range that has typically been reported for other avian species $\left(10^{-7}\right.$ to $10^{-5} \mathrm{M}$, reviewed by Roper 1999), the dose response curve did not reach threshold, suggesting that blue petrels can probably detect even weaker concentrations than those we tested (see Nevitt \& Bonadonna 2005a). In earlier experiments in which we used this technique to test blue petrel chicks' responses to a single concentration of DMS, we found that response depended on satiation state (Cunningham et al. 2003) and, potentially, age (Cunningham unpubl. data). In the present experiment, our results showed no significant correlation with these variables, suggesting that neither hunger nor age influenced responsiveness. In interpreting our results, we caution that a limitation of this non-invasive, behavioral assay is that it does not discriminate between an olfactory and a nociceptive (trigeminal or common chemical sense) response. Humans experience this sense in response to various spices (capsassin in chili peppers, horse radish, or garlic, for example), whereas birds are sensitive to different compounds that may or may not also stimulate the olfactory system (for review see Clark 1998). In any event, both pathways may be involved in mediating the detection of scented compounds in natural situations, depending on the context and the concentration (Clark 1997). With respect to our study, we did not observe chicks recoiling from stimulus presentations as might be expected for a trigeminal irritant, and chicks responded at stimulus concentrations that are more typically attributed to olfactory perception $\left(<10^{-5} \mathrm{M}\right.$, Kirifides et al. 2004). Behavioral responses were also qualitatively similar to those we have observed in similar tests using established foraging odors (e.g. DMS, Cunningham et al. 2003).

\section{Potential role of ammonia as a foraging cue}

The sensitivity range suggests that the blue petrel Halobaena caerulea may be able to use ammonia as a signal molecule for detecting prey patches, and this is a topic that deserves further research. Ammonium is the major excretion product of seabird prey, including schooling mesopelagic fish and krill swarms. Although ammonium is taken up by phytoplankton through nitrogen recycling, it has also been shown to accumulate in surface seawater for at least several hours in association with dense krill swarms. For example, Johnson et al. (1984), measured ammonium $\left(\mathrm{NH}_{4}{ }^{+}\right)$ levels within a krill swarm to be on average $0.75 \mathrm{mmol}$ $\mathrm{m}^{-3}\left(7.5 \times 10^{-7} \mathrm{M}\right)$ higher than in adjacent seawater and suggested that these levels were generated by excretion over a period of $15.5 \mathrm{~h}$. 
While it is not known how much of this ammonium is volatilized, the discovery that blue petrels are responsive to picomolar solution concentrations suggests that they may be able to use trace emissions to identify productive foraging areas. Marine ammonia emissions have not been as well studied in the sub-Antarctic as emissions of other trace gases. However, empirical measurements taken in the remote Pacific (Quinn et al. 1988, 1990, as cited by Nightingale \& Liss 2004) suggest that the sea-to-air flux of $\mathrm{NH}_{3}$ is similar in size to DMS emissions. Blue petrels are sensitive to DMS at sea, and chicks also respond to it using the Porter method (e.g. Nevitt et al. 1995, Nevitt 2000, Cunningham et al. 2003). Moreover, the foraging behavior of blue petrels involves searching remote, offshore areas for patchily distributed prey in pelagic waters (e.g. Chaurand \& Weimerskirch 1994), where the signal-tonoise ratio for ammonia and other trace gases emitted into the atmosphere in association with zooplankton aggregations is likely to be high (see discussion in Larsen et al. 2001). Large fetch, wave action and wind, all typical of the Southern Ocean environment, should increase the rate of transfer between seawater and air. Wave spray will tend to aerosolize ammonia in solution, while low temperatures will tend to reduce the atmospheric equilibrium concentration and the extent of volatilization (Liss \& Galloway 1993, Liss et al. 2004).

With respect to signaling prey availability to birds, we speculate that signals should be strongest when prey is closest to the surface, since it has previously been established that ammonium concentrations in surface seawater reflect vertical migratory patterns of mesozooplankton. For example, Priddle et al. (1997) showed that ammonium concentrations in near-surface (top $30 \mathrm{~m}$ ) water around South Georgia varied diurnally, with maximum values reaching $1.3 \mathrm{mmol} \mathrm{m}^{-3}$ $\left(1.3 \times 10^{-6} \mathrm{M}\right)$ near local midnight, dropping to as low as $0.1 \mathrm{mmol} \mathrm{m}^{-3}\left(1 \times 10^{-7} \mathrm{M}\right)$ around noon. Thus, if blue petrels can detect volatilized ammonia at sea and use it to locate, recognize, or otherwise evaluate potential prey hotspots, then this ability may be most useful at night when prey is closest to the surface and when visual cues are obscured. In support of this hypothesis, the correlation between prey availability and diet implies that at least some foraging occurs at night (e.g. Croxall et al. 1999, Cherel et al. 2002). However, the mechanisms by which blue petrels locate prey are not completely understood, particularly in terms of elucidating the interaction between olfactory and visual cues with respect to prey capture (see Nevitt 2000). Clearly, the combined evidence suggests that volatilized ammonia may be an important signal molecule for this species, but whether blue petrels and other procellariiforms can use it as a foraging cue at sea will require further investigation.

\section{Ammonia as a signal molecule in the terrestrial habitat}

A common assumption is that procellariiform seabirds navigate to islands by simply seeing them in the distance, but this perspective overlooks the fact that other species do not share the same sensory world as humans (for reviews see Dusenbery 1992, Wiltschko \& Wiltschko 1994 and Goodenough et al. 2000). For example, previous studies have suggested that olfactory features of island habitat are likely to be as distinctive for procellariiforms as visual features are for humans (reviewed by Nevitt \& Bonadonna 2005a). With respect to homing, Grubb (1974) showed that Leach's storm-petrels Oceanodroma leucorhoa translocated just $500 \mathrm{~m}$ from their nesting colonies failed to relocate their burrows if their olfactory nerves were transected. Moreover, intact birds consistently approached colony sites by zigzagging upwind (Grubb 1974; see also Griffin 1940, Billings 1968, Grubb 1973), suggesting an olfactory-mediated search (see Dusenbery 1992 for detailed descriptions of olfactory search). More recent studies indicate that similarly displaced blue petrels Halobaena caerulea and thin-billed prions Pachyptila belcheri fail to relocate nest sites when rendered temporarily anosmic (smell-blind) (Bonadonna et al. 2001, 2004). While vocalizations are audible in colonies, these results indicate that auditory cues provided by mates and conspecifics were insufficient for nest site relocation at these spatial scales. At greater distances, procellariiforms may be able to use magnetic cues for orientation and navigation, but a variety of species can still home accurately, even when the local magnetic field has been experimentally disrupted (e.g. white-chinned petrels Procellaria aequinoctialis: Benhamou et al. 2003, Bonadonna et al. 2005).

Although procellariiform seabirds doubtless use a hierarchy of cues in long-distance navigation (Nevitt \& Bonadonna 2005b), the demonstration that petrels can detect volatilized ammonia indicates that it is a potential odor landmark used for homing to islands, particularly at night or in fog when other cues are obscured. SubAntarctic islands are detectable by smell from a distance, even to humans, due to the large number of seabirds and marine mammals that tend to breed on them. A primary component of this characteristic odor can be attributed to nitrogen waste, and in particular, to volatilized ammonia. For example, on Macquarie Island, Erskine et al. (1998) found volatilized ammonia in the air spaces $1 \mathrm{~m}$ above penguin colonies, and were able to trace the transfer of this ammonia inland as well as out to sea. In Antarctica, ammonia transfer from penguin colonies has been traced as far as $15 \mathrm{~km}$ (Rankin \& Wolff 2000). These data suggest that the odor signature around inhabited islands is a prominent feature for those animals that can detect it. 
The association of ammonium with inhabited islands suggests that ammonia and associated scents may contribute to the sensory cues birds use to evaluate habitat before choosing to nest there for the first time. For example, nitrogen signatures also give local information about where nesting sites are or have been historically (see Lindeboom 1984, Erskine et al. 1998, Bergstrom et al. 2002). On Macquarie Island, soils from direct excrement zones of nesting animals, especially soils associated with burrowing petrels, had a substantially higher concentration of soluble nitrogen than soil samples collected away from such influence (Erskine et al. 1998). Total soluble nitrogen levels were highest $(1.8 \pm-0.4 \mu \mathrm{M}$ $\mathrm{g}^{-1}$ dry wt) at a burrowing petrel site, surpassing those in soils collected from penguin colonies (1.61 \pm 0.3 to $0.8 \pm-0.1)$, elephant seal wallows $(0.2 \pm-0.1)$, light-mantled, sooty albatross, nesting sites $(0.6 \pm-0.2)$, and areas frequented by skuas and non-indigenous rabbits (0. \pm-0.2$)$, giant petrels $(1.2 \pm-0.1)$ and humans $(0.5 \pm$ $-0.2)$. The dominant soluble form of nitrogen was ammonium, whereas concentrations of other forms (nitrate, urea, uric acid and amino acids) were comparatively low. Soils sampled at the burrowing petrel site also contained $45 \%$ protein - double to that at any other site. These data are noteworthy, since urinary proteins have been linked to individual recognition in other species (mice, e.g. Hurst et al. 2001) and could also be explored in the context of burrow or individual recognition (Bonadonna et al. 2001, 2004, Bonadonna \& Nevitt 2004).

\section{CONCLUSIONS}

The results presented here suggest that blue petrels can detect ammonia at concentrations pertinent to both foraging and navigation. The extreme sensitivity suggests that blue petrels may be able to use volatilized ammonia to detect prey patches at sea, and this is a topic that deserves further research. For example, with respect to multi-level ecological monitoring programs, our results suggest that examining the relationship between seabird distributions and seawater ammonium concentrations may provide insights into the foraging behavior of birds and other predators (Serebrennikova \& Fanning 2002, Chapman et al. 2004), particularly with respect to the mechanisms used to find prey. In the context of homing, a picture is emerging that sub-Antarctic islands represent prominent olfactory features in the sensory landscape in which blue petrels and other procellariiforms operate. Our results thus establish volatilized ammonia as a measurable, biogenic, scented compound in the hierarchy of cues that these birds have available to them to relocate their home islands. The possibility that petrels use ammonium as a cue for evaluating potential breeding areas needs to be further explored.
Acknowledgements. We are grateful to the Institut Polaire Français Paul Emile Victor (IPEV) and NSF (No. OPP 0229775, IBN-0212467) for financial and logistical support. We thank N. Willets of the UC Davis Statistical Consulting Laboratory for advice, and R. Larsen for his thoughtful guidance with respect to air-sea ammonia exchange. J. DeBose and R. Kihslinger were helpful in preparing this manuscript. All experiments adhered to guidelines established by IPEV for the ethical treatment of animals.

\section{LITERATURE CITED}

Atkinson A, Whitehouse MJ (2000) Ammonium excretion by Antarctic krill Euphausia superba at South Georgia. Limnol Oceanogr 45:55-63

Atkinson A, Whitehouse MJ (2001) Ammonium regeneration by Antarctic mesozooplankton: an allometric approach. Mar Biol 139:301-311

Benhamou S, Bonadonna F, Jouventin P (2003) Successful homing of magnet-carrying white-chinned petrels released in the open sea. Anim Behav 65:729-734

Bergstrom DM, Stewart GR, Selkirk PM, Schmidt S (2002) ${ }^{15} \mathrm{~N}$ natural abundance of fossil peat reflects the influence of animal-derived nitrogen on vegetation. Oecologia 130: 309-314

Billings SM (1968) Homing in Leach's petrel. Auk 85:36-43

Bonadonna F, Nevitt GA (2004) Partner-specific odor recognition in an Antarctic seabird. Science 306:835

Bonadonna F, Spaggiari J, Weimerskirch H (2001) Could osmotaxis explain the ability of blue petrels to return to their burrows at night? J Exp Biol 204:1485-1489

Bonadonna F, Villafane M, Bajzak C, Jouventin P (2004) Recognition of burrow's 'olfactory signature' in blue petrels, Halobaena caerulea: an efficient discrimination mechanism in the dark. Anim Behav 67:893-898

Bonadonna F, Bajzak C, Benhamou S, Igloi K, Jouventin P, Lipp HP, Dell'Omo G (2005) Orientation in the wandering albatross: interfering with magnetic perception does not affect orientation performance. Proc R Soc Lond B 272: 489-495

Chapman EW, Ribic CA, Fraser WR (2004) The distribution of seabirds and pinnipeds in Marguerite Bay and their relationship to physical features during austral winter. 2001. Deep-Sea Res II 51:2261-2278

Chaurand T, Weimerskirch H (1994) The regular alternation of short and long foraging trips in the blue petrel Halobaena caerulea: a previously undescribed strategy of food provisioning in a pelagic seabird. J Anim Ecol 63(2): 275-282

Cherel Y, Bocher P, Trouve C, Weimerskirch H (2002) Diet and feeding ecology of blue petrels Halobaena caerulea at Iles Kerguelen, Southern Indian Ocean. Mar Ecol Prog Ser 228:283-299

Clark L (1997) A review of the bird repellent activity of 117 aromatic compounds. In: Mason JR (ed) Repellents in wildlife management. Utah State University Press, Logan, UT, p 243-252

Clark L (1998) The physiological, behavioral, ecological and evolutionary bases for the avoidance of chemical irritants by birds. Curr Ornithol 14:1-39

Croxall JP, Reid K, Prince PA (1999) Diet, provisioning and productivity responses of marine predators to differences in availability of Antarctic krill. Mar Ecol Prog Ser 177: $115-131$

Cunningham GB, VanBuskirk RW, Bonadonna F, Weimerskirch H, Nevitt GA (2003) A comparison of the olfactory 
abilities of three species of procellariiform chicks. J Exp Biol 206:1615-1620

Dacey JWH, Wakeham SG (1986) Oceanic dimethylsulfide: production during zooplankton grazing on phytoplankton. Science 233:1314-1316

Daly KL, DiTullio GR (1996) Particulate dimethylsoniopropionate removal and dimethyl sulfide production by zooplankton in the Southern Ocean. In: Kiene RP, Visscher PT, Kellor MD, Kirst GO (eds) Biological and environmental chemistry of DMSP and related sulfonium compounds. Plenum Press, New York, p 223-238

Daniel WW (1990) Applied nonparametric statistics. PWSKENT, Boston, MA

Dusenbery D (1992) Sensory ecology: how organisms acquire and respond to information. WH Freeman, New York

Erskine PD, Bergstrom DM, Schmidt S, Stewart GR, Tweedie CE, Shaw JD (1998) Sub-Antarctic Macquarie Island-a model ecosystem for studying animal-derived nitrogen sources using ${ }^{15} \mathrm{~N}$ natural abundance. Oecologia 117: 187-193

Goodenough J, McGuire B, Wallace RA (2000) Perspectives on animal behavior. John Wiley \& Sons, Hoboken, NJ

Griffin DR (1940) Homing experiments with Leach's petrels. Auk 57:61-74

Grubb TC (1973) Colony location by Leach's petrel. Auk 90: $78-82$

Grubb TC (1974) Olfactory navigation to the nesting burrow in Leach's petrel (Oceanodroma leucorrhoa) Anim Behav 22:192-202

Hurst JL, Payne CE, Nevison CM, Marie AD, Humphries RE, Robertson DHL, Cavaggioni A, Beynon RJ (2001) Individual recognition in mice mediated by major urinary proteins. Nature 414:631-634

Johnson MA, Macaulay MC, Biggs DC (1984) Respiration and excretion within a mass aggregation of Euphausia superba-implications for krill distribution. J Crustac Biol 4:174-184

Jouventin P, Mougin, JL, Stahl JC, Weimerskirch H (1985) Comparative biology of the burrowing petrels of the Crozet Islands. Notornis 32:157-220

Kasamatsu N, Kawaguchi S, Watanabe S, Odate T, Fukuchi M (2004) Possible impacts of zooplankton grazing on dimethylsulfide production in the Antarctic Ocean. Can J Fish Aquat Sci 61:736-743

Kirifides ML, Kurnellas MP, Clark L, Bryant BP (2004) Calcium responses of chicken trigeminal ganglion neurons to methyl anthranilate and capsaicin. J Exp Biol 207:715-722

Larsen RK, Steinbacher JC, Baker JE (2001) Ammonia exchange between the atmosphere and the surface waters at two locations in the Chesapeake Bay. Environ Sci Technol 35:4731-4738

Lindeboom HJ (1984) The nitrogen pathway in a penguin rookery. Ecology 65:269-277

Liss PS, Galloway JN (1993) Air-sea exchange of sulphur and nitrogen and their interaction in the marine atmosphere. In: Wollast R, Mackenzie FT, Chou L (eds) Interactions of $\mathrm{C}, \mathrm{N}, \mathrm{P}$ and $\mathrm{S}$ biogeochemical cycles and global change. Springer-Verlag, Berlin, p 259-281

Liss PS, Adele L, Chuck SM, Turner M, Watson AJ (2004) Air-sea gas exchange in Antarctic waters. Antarct Sci 16: 517-529

Nevitt GA (1999) Olfactory foraging in Antarctic seabirds: a species-specific attraction to krill odors. Mar Ecol Prog Ser

Editorial responsibility: Howard I. Browman (Associate Editor-in-Chief), Storebø, Norway
$177: 235-241$

Nevitt GA (2000) Olfactory foraging by Antarctic procellariiform seabirds: life at high Reynolds numbers. Biol Bull (Woods Hole) 198:245-253

Nevitt GA, Bonadonna F (2005a) Seeing the world through the nose of a bird: new developments in the sensory ecology of procellariiform seabirds. Mar Ecol Prog Ser 287:292-295

Nevitt GA, Bonadonna F (2005b) Sensitivity to dimethyl sulphide suggests a mechanism for olfactory navigation by seabirds. Proc R Soc Biol Lett 1(3):303-305

Nevitt GA, Veit RR (1999) Mechanisms of prey patch detection by foraging seabirds. In: Adams NJ, Slotow RH (eds) Proceedings of 22nd International Ornithological Congress, Durban, South Africa. BirdLife-South Africa, Johannesburg, p 2027-2082

Nevitt GA, Veit RR, Kareiva P (1995) Dimethyl sulphide as a foraging cue for Antarctic procellariiform seabirds. Nature 376:680-682

Nevitt GA, Reid K, Trathan PN (2004) Testing olfactory foraging strategies in an Antarctic seabird assemblage. J Exp Biol 207:3537-3544

Nightingale PD, Liss PS (2004) 6.03 Gases in seawater. In: Elderfield $\mathrm{H}$ (ed) Treatise on geochemistry, Vol 6. The oceans and marine geochemistry. Elsevier, Amsterdam, p 49-81

Porter RH, Hepper PG, Bouchot C, Picard M (1999) A simple method for testing odor detection and discrimination in chicks. Physiol Behav 67:459-462

Priddle J, Whitehouse MJ, Atkinson A, Brierley AS, Murphy EJ (1997) Diurnal changes in near-surface ammonium concentration-interplay between zooplankton and phytoplankton. J Plankton Res 19:1305-1330

Quinn PK, Charlson RJ, Bates TS (1988) Simultaneous observations of ammonia in the atmosphere and ocean. Nature 335:336-338

Quinn PK, Bates TS, Johnson JE, Covert DS, Charlson RJ (1990) Interactions between the sulfur and reduced nitrogen cycles over the central Pacific Ocean. J Geophys Res 95:16405-16416

Rankin AM, Wolff EW (2000) Ammonium and potassium in snow around an emperor penguin colony. Antarct Sci 12: $154-159$

Roper TJ (1999) Olfaction in birds. Adv Stud Behav 28: 247-332

Sawyer CN, McCarty PL (1978) Chemistry for environmental engineering, 3rd edn. McGraw-Hill, New York

Serebrennikova YM, Fanning KA (2002) Nutrients in the Southern Ocean GLOBEC region: variations, water circulation, cycling. Deep-Sea Res II 51:1981-2002

Shirihai H (2002) A complete guide to Antarctic wildlife: the birds and marine mammals of the Antarctic continent and Southern Ocean. Alula Press, Degerby

Silverman E, Veit RR, Nevitt GA (2004) Nearest neighbors as foraging cues: information transfer in a patchy environment. Mar Ecol Prog Ser 277:25-36

Weimerskirch H, Zotier H, Jouventin P (1989) The avifauna of the Kerguelen Islands. Emu 89:15-29

Wiltschko R, Wiltschko W (1994) Avian orientation: multiple sensory cues and the advantage of redundancy. In: Davies MNO, Green PR (eds) Perception and motor control in birds. Springer-Verlag, Berlin, p 95-119

Zar JH (1996) Biostatistical analysis, 3rd edn. Prentice-Hall, Upper Saddle River, NJ

Submitted: August 1, 2005; Accepted: November 28, 2005

Proofs received from author(s): May 31, 2006 